\title{
NUKENTĖJĘ NEPILNAMEČIAI NUO SEKSUALINIŲ NUSIKALTIMŲ - PSICHOLOGINIO (EKSPERTINIO) TYRIMO SVARBA ATPAŽINTI KLAIDINGUS ITTARIMUS
}

\author{
Dovilè Prižginė, Agnė Šiaulytė \\ Valstybine teismo psichiatrijos tarnyba prie Sveikatos apsaugos ministerijos
}

Raktažodžiai: seksualinė prievarta prieš vaikus, seksualinès prievartos prieš vaikus įtarimų vertinimas, seksualine prievarta prieš vaikus ir konfliktiškos skyrybos.

\begin{abstract}
Santrauka
Seksualinès prievartos prieš vaikus atvejus yra sudètinga tirti, nes dažnai vaikai yra ne tik pagrindiniai, bet ir vieninteliai liudytojai bylose. Ypač sudètinga vertinti, kai ịtarimai dèl seksualinès prievartos pareikšti vaiko tèvui arba motinai tẻvų skyrybų kontekste. Šiuo straipsniu siekta 1) apžvelgti literatūrą šia tema, 2) apžvelgti veiksnius, turinčius įtakos vaikui, kaip patikimam liudytojui, tokiose bylose, 3) atvejo analizès tyrimo metodo pagrindu išanalizuoti Vaikų ir paauglių teismo psichiatrijos skyriuje 2009-2014 metais atliktų kompleksinių teismo psichiatrijos-psichologijos ekspertizių duomenis, kai ịtarimai dèl seksualinès prievartos pareikšti nukentejusiujų tèvui arba motinai, apimant ir tėvų skyrybų kontekstą.
\end{abstract}

\section{Ivadas}

Seksualinè prievarta prieš nepilnamečius yra paplitęs reiškinys, reikšmingai žalojantis vaikų sveikatą ir trikdantis jų vystymąsi. Nepaisant to, daugejja atvejų, kuriuose pareikšti ịtarimai dèl seksualinio vaiko išnaudojimo yra klaidingai suprantami ir/ar ịvertinami tiek šioje srityje dirbančių specialistų, tiek neprofesionalų $(1,2)$. Netiksliai ivvertinti įtarimai sąlygoja dvi pagrindines klaidas:

- seksualinès prievartos fakto paneigimą, kai iš tiesų ji buvo (yra atliktų tyrimų su vaikysteje seksualinę prievartą patyrusiais suaugusiais, kurie teigè, jog, vaikystejje aplinkiniams papasakojus apie patirtą smurtą, jais niekas netikèjo);

- $\quad$ seksualinės prievartos fakto nustatymą, kai iš tiesų jos nebuvo (ne vienas autorius aprašè klaidingų itarimu neigiamas pasekmes neteisingai apkaltintam smurtautojui).
Kiekviena iš minètų ịvertinimo klaidų yra susijusi su reikšmingais neigiamais padariniais:

- jei įtarimai yra teisingi, tačiau jais netikima, vaikas ir toliau gyvena prieš ji smurtaujančioje aplinkoje, o tai savo ruožtu dar labiau trikdo nukentejjusiojo raidą;

- jei itarimai yra klaidingi, tačiau jais yra tikima, tada kaltinamasis ir jo šeima susiduria su nepagrista kančia (1).

Didžiausias iššǔkis, su kuriuo tyrèjai susiduria, vertindami klaidingus seksualinès vaiko prievartos įtarimus, apima teisingų ir klaidingų ịtarimų kriterijų nustatymą. Sąvokos „pagrịstas ịtarimas“ ir „nepagrịstas įtarimas“ kuria sumaištį. Nepagrịstas ịtarimas negali būti prilyginamas klaidingam įtarimui. Visada galime diskutuoti, ar didesnis kiekis informacijos bei kitoks požiūris padètų ittarimus labiau pagrịsti? Analogiška mintis - ar pagrịstas įtarimas visada reiškia, jog jis yra teisingas? Taigi, tyrejai sutinka, jog klaidingas įtarimas dažniausiai reiškia vieną iš sekančių variantų: 1) visas įtarimas yra netiesa, tai reiškia, jog nè vienas iš įtarime nurodytų ịvykių neįvyko; 2) ịtarimas, kuriuo yra apkaltinamas nusikaltimo neịvykdęs asmuo, tačiau pats ịtarimas yra teisingas. Šiuo atveju įvyksta vadinamasis „kaltininko pakeitimas“, kai vaikas papasakoja apie patirtą seksualinę prievartą, tačiau nurodo ne tikraji smurtautoją; 3) įtarimas, kurio turinys turi tiek teisingu, tiek klaidingu aplinkybių. Tai reiškia, jog tam tikri vaiko apibūdinami ịvykiai yra teisingi (iš tiesų ịvykę), tačiau ị savo pasakojimą jis ịpina ir klaidingas įvykių aplinkybes, kurių realybeje nebuvo (1).

Skaičiavimai rodo, jog klaidingai pareikštų įtarimų (kai seksualinès vaiko prievartos faktas nepasitvirtino) dažnumas svyruoja nuo 2 iki 8 procentu, ir šis rodiklis yra aukštesnis skyrybų ginčuose. Minèti apskaičiavimai neapima tụ atvejų, kuriems patvirtinti/paneigti ịtarimus pritrūko informacijos. Seksualinès vaikų prievartos atvejų tyrimai rodo, jog klaidingi įtarimai yra retai pasitaikantys (mažiau nei 10 procentų nuo visų pareikštų itarimų), o jei apie patiriamą lytinị smurtą pirmas pasipasakoja vaikas, klaidingų įtarimų 
dažnumas dar labiau sumažèja. Kitos klaidingų įtarimų formos (ankščiau minètas „kaltininko pakeitimas“ ar įtarimai, kurių turinys apima tiek teisingas, tiek klaidingas įvykių aplinkybes) yra mažiau tyrinejjamos, todèl sunkiau įvertinti tikslesnį tokių atvejų dažnumą $(1,3)$.

Nustatyti pareikštų ịtarimų teisingumą/klaidingumą nèra lengva, nes paprastai vienintelis įrodymas, kuriuo tokio pobūdžio bylose yra remiamasi, yra vaiko parodymai. Daugelis klinicistų bei tyrejjų, vertindami seksualinès prievartos faktą, stebi nukentejusiujų vaikų emocinius ir elgesio pokyčius, atsiradusius po patirtos traumuojančios patirties. Simptomai, dažniausiai cituojami specialistų, apima miego sunkumus, padidejusį nerimą, regresyvų elgesį, enurezę, depresinę nuotaiką ir netinkamus su lytiškumu susijusius veiksmus. Nors minèti simptomai gali būti sąlygoti patirtos seksualinès prievartos, tačiau jie daugiau atspindi būsenos ir elgesio pokyčius, kuriuos sukelia bet kokia kita trauminè vaiko patirtis. Amžiaus neatitinkantis seksualizuotas vaiko elgesys yra vienintelis požymis, labiausiai siejamas su seksualinès prievartos patirtimi. Svarbu pabrěžti, jog tam tikras su lytiškumu susijęs vaiko elgesys (pvz., domèjimasis genitalijomis, klausinèjimas apie lyčių skirtumus ir pan.) gali būti normalus ir atitinkantis vaiko amžiaus tarpsni, todèl specialistams, dirbantiems su nukentejusiais nuo seksualinès prievartos nepilnamečiais, svarbu atskirti, koks elgesys yra normalus vaiko amžiui, o dèl kurio reikètų susirūpinti. Kalbant bendrai apie vaikų būsenos ir elgesio pokyčius, padedančius įvertinti įtarimų teisingumą/klaidingumą, būtina atkreipti dèmesị i tai, jog minètų simptomų nebuvimas nepaneigia seksualinės prievartos fakto, kaip ir vien tik jų nustatymas nèra pakankama sąlyga, kad toks faktas būtų patvirtintas (1-3).

Seksualinès prievartos prieš nepilnamečius bylose nèra neịprasta, kai proceso eigoje nukentejusieji atsiima pirminius savo parodymus, kurių metu atskleide, jog buvo lytiškai tvirkinami/prievartaujami. Autoriai pastebi, jog pareikšti ịtarimai smurtautojui neretai suardo nusistovejjusią šeimos struktūrą. Vaikas gali patirti stiprų spaudimą suaugusiuju, siekiančių išlaikyti šeimos stabilumą, todèl tokiais atvejais nukentejęs nepilnametis neretai paneigia pirmini prievartos atskleidimą. Vaikas, davęs pirminius parodymus apie patirtą smurtą, gali išgyventi didelę atsakomybę už šeimoje ịvykusius neigiamus pokyčius, todèl jis linkęs pasirinkti melą vardan santarvès artimiausioje jam aplinkoje. Literatūroje pabrèžiama, jog pirminių parodymų atsižadèjimas nebūtinai reiškia, jog pareikšti ịtarimai yra teisingi arba klaidingi, tačiau tai yra svarbus signalas aplinkiniams, jog vaiko gyvenime ne viskas yra gerai, nepriklausomai nuo jo būsenos pokyčių priežasčių: seksualinès prievartos jo atžvilgiu, disfunkcijos šeimoje ar kitų stresogeninių situ- acijų ne artimiausioje vaiko aplinkoje (1).

Analizuojant pareikštų ịtarimų teisingumą/klaidingumą, yra taip pat taikoma parodymų patikimumo vertinimo technika, kuri yra reikšminga tiek teoriniu, tiek praktiniu požiūriu. Tam, kad parodymų patikimumo vertinimas būtų atliktas efektyviai, apie patirtą seksualinę prievartą nukentejusysis privalo papasakoti pusiau struktūruotos jo apklausos metu. Po minètos vaiko apklausos atliekama parodymų analizè, kurią sudaro du komponentai: aiškiais kriterijais grissta parodymų turinio analize ir parodymų pagristumo patikrinimas. Vaiko parodymų patikimumo vertinimas reikalauja didelio teorinio pasiruošimo ir ilgalaikio praktinio darbo, kad specialistas, taikantis ši metodą, būtų pakankamai ịgudęs (4).

Literatūroje aprašomos įvairios priežastys, sąlygojančios klaidingų įtarimų dél seksualinio vaiko išnaudojimo atsiradimą. Daugelis iš jų yra inicijuojami suaugusiųų, keletas iš jų - pačių vaikų, dar kiti yra neprofesionaliai atlikto tyrimo rezultatas. Itarimai, kuriuos inicijuoja suaugusieji, dažniausiai kyla teisminių ginčų dèl vaiko gyvenamosios vietos/bendravimo su vaiku nustatymo kontekste. Klaidingi itarimai, kuriuos inicijuoja vaikas, yra pasitaikantys rečiau, taip pat jie nèra intensyviai tyrinejjami. Tokiais atvejais, priklausomai nuo situacijos, nepilnametis gali „išpūsti“ parodymų turini arba atvirkščiai - ji sumenkinti. Vyresni vaikai ar paaugliai gali klaidingai apkaltinti suaugusiji seksualine prievarta, vedini keršto jausmo dèl realaus ar ịsivaizduojamo pasikèsinimo ị jų gerovę. Neretai tokiu elgesiu nepilnametis siekia ịgti daugiau kontrolès tose situacijose, kuriose jis jaučiasi bejègis. Neprofesionaliai atliktas tyrimas taip pat gali būti klaidingų įtarimų šaltinis. Dažniausiai tam ịtakos turi menki apklausą vykdančio specialisto ịgūdžiai, būtini objektyviam, i faktų nustatymą orientuotam tyrimui. Kadangi dažniausiai klaidingi ịtarimai kyla teisminių ginčų dèl gyvenamosios vaiko vietos/bendravimo su vaiku kontekste, tai tolimesnèse pastraipose aptariamas tokių atvejų vertinimo specifiškumas ir kompleksiškumas (1).

Nors daugelis tyrejjų sutaria, jog didžiausias klaidingų įtarimų procentas kyla skyrybų ginčuose dèl gyvenamosios vaiko vietos/bendravimo su juo tvarkos nustatymo, tačiau specialistai nesutaria dèl jų skaičiaus. Skirtingų autorių paskaičiavimu, minètuose ginčuose klaidingų ịtarimų dažnumas svyruoja nuo 20 iki 80 procentų. Daugelyje šių atvejų kriterijus, nulėmęs įtarimų pripažinimą klaidingais, buvo ne teismo sprendimas, o vaiko teisių apsaugos specialistų, vaiko gyvenamosios vietos vertintojų (dažniausiai psichologų) išvada. Itarimų, kylančių skyrybų ginčų kontekste, vertinimas susiduria su neịprastais sunkumais. Tokị vertinimą dar labiau komplikuoja mažas nukentėjusiojo amžius, suaugusiujų motyvacija bei poreikis ginti teises ir in- 


\section{6}

teresus tiek paties vaiko, tiek įtariamojo smurtautojo $(1,3)$.

Didelę įtaką teisminiam skyrybų ginčų procesui turèjo ìvykę esminiai šeimos teisès ir požiūrio i̇ vaikų auginimą bei auklëjimą pokyčiai. Skyrybų skaičius išaugo visose amžiaus grupèse. Kadangi bendras skyrybų skaičius didèja, ta nemaža dalis su jomis susijusių negatyvių ịsitikinimų tai pat praranda reikšmę. Pavyzdžiui, daugelyje Šiaurès Amerikos valstijų buvo priimtas teisès aktas, kuriuo, siekiant nutraukti dviejų žmonių santuoką, nèra reikalaujama įrodyti vieno iš jų kaltę. Nepaisant šių teisinių pokyčių, besiskiriantys sutuoktiniai nenustoja jausti nuoskaudos ar vienas ant kito pykti. Tokiais atvejais daugeliui iš jų nelieka nieko kito, kaip tik kautis dèl vaikų, todèl pastaruoju metu stebimas tokių ginčų padažnejjimas. Be vadinamujų ,niekieno kaltè" teisinių pakeitimų, atsirado nauji įstatymai, kuriais remiantis, gyvenamoji vaiko vieta nebepriskiriama tik motinai - tèvas, jei išreiškia norą, gali jos taip pat siekti. Nemažą îtaką išaugusiam ịtarimų dèl seksualinės vaikų prievartos skyrybų kontekste skaičiui daro ir žiniasklaida, kuri vis dažniau ịspejja visuomenę būti budrią, stebint fizinius vaiko simptomus bei jo elgesio pokyčiams, galinčius signalizuoti apie patiriamą smurtą, bei atitinkamai reaguoti - apie įtarimus pranešti atitinkamoms institucijoms (3).

Autoriai atkreipia dèmesị ị kitą medalio pusę - priežastis, dèl kurių pareikšti įtarimai dèl seksualinio vaiko išnaudojimo gali pasitvirtinti tik skyrybų ginčų metu. Nukentejęs vaikas gali bijoti pasakoti apie smurtautojo veiksmus, kol visi šeimos nariai vis dar yra kartu. Vaikas, kuriam grasinama, jog papasakojimas apie prievartą kitiems išardys šeimą, gali pradèti apie tai kalbèti tik tada, kai tėvai skiriasi, mat kartu negyvenančiam tèvui yra daug sunkiau daryti aukai spaudimą, jog apie smurtą ji niekam neprasitartų. Taip pat nukentėjęs vaikas gali jausti didelę baimę, prieš eidamas susitikti teismo paskirtu laiku su kartu negyvenančiu smurtautoju, todèl, siekdamas išvengti susidūrimo, gali imti pasakoti apie patirtą seksualinę prievartą. Bet kuriuo atveju autoriai pabrèžia, jog nepriklausomai nuo to, ar įtarimai, kilę skyrybu ginčų metu, pasitvirtina, ar ne, jie vis tiek yra susiję su neigiamomis psichologinès vaiko gerovès pasekmėmis. Net jei tẻvai išsigalvoja seksualinès vaiko prievartos faktą, pernelyg jautriai reaguodami ị atžalos emocinius ir elgesio pokyčius, tai taip pat, kaip ir pats smurtas, turi neigiamos įtakos emocinei vaiko sveikatai (3).

Pastebètina, jog emociniai ir elgesio pokyčiai, pasireiškiantys vaikams, kurių tèvai skiriasi, bei simptomai, kurie yra susiję su seksualinės prievartos patyrimu, yra panašūs. Tai ypač aktualu kalbant apie nespecifinius emocinius ir elgesio požymius, kurie yra stebimi tiek vienos, tiek kitos trauminès patirties metu. Minèti požymiai apima depresinę nuotaiką, baimę, nerimą, pyktį, sumažejusi pasitikèjimą savimi, psichosomatines problemas, sunkumus mokykloje, problemas su bendraamžiais. Specialistai, vertindami minètus požymius bei juos susiedami su juos sąlygoti galèjusia traumine patirtimi, naudoja ịvairias technikas. Svarbi tokio ịvertinimo sąlyga yra turèti pakankamai žinių apie abiejų trauminių patirčių - skyrybų ir patirtos seksualinès prievartos - psichologiją. Visų pirma, specialistas turi būti susipažinęs su nespecifinių simptomų etiologija. Pavyzdžiui, jei vertinimo metu yra stebimas mažas vaiko pasitikèjimas savimi, specialistas privalo detaliau ịvertinti, kaip nukentèjusysis save mato ir kodèl. Jei vertintojas, remdamasis visais tyrimo metu gautais duomenimis, mato, jog vaikas jaučia pasišlykštèjimą savo kūnu ir pokalbio metu atskleidžia, jog įtariamas smurtautojas išsako nukentẻjusiojo kūno atžvilgiu nepadorius komentarus, tai galima kelti pagrịstą prielaidą, jog vaikas galimai patiria seksualinę prievartą. Kita vertus, vaikas, kurio nepasitikejjimas savimi kyla iš jausmo, jog jis yra nemylimas ir paliktas kartu negyvenančio tẻvo, labiau kenčia nuo skyrybų traumos (1-3).

Nepaisant to, jog galutini sprendimą dèl seksualinès vaiko prievartos priima teismas, tačiau savalaikis specialistų, padedančių ịvertinti ịtarimų teisingumą, vaidmuo turi reikšmingos įtakos teisèjų išvadai. Nors nèra konkretaus testo, kurio pagalba skyrybų ginčuose kilę ịtarimai dèl seksualinès vaiko prievartos būtų patvirtinti arba atmesti, tačiau yra sukaupta nemažai profesinès literatūros, padedančios tiksliau įvertinti įtarimų teisingumą. Joje rašoma, jog ittarimai, apie kuriuos pirmieji ima kalbèti vaiko tèvai, o ne pats nukentejusysis, rečiau pasitvirtina. Maži vaikai retai kada spontaniškai ir savarankiškai ims kalbèti apie klaidingas seksualinès prievartos jų atžvilgiu aplinkybes. Dažniausiai tokiais atvejais jų pasakojimui didelès įtakos turi suaugusiujų, kurie tiki įtarimų teisingumu, poveikis. Labai svarbu pabrěžti, jog daugelis skyrybų ginčų kontekste pareikštų klaidingų ịtarimų nèra sąmoningos fabrikacijos. Sąmoningas melas apie seksualinę vaiko prievartą, siekiant vaiko globos, yra retas reiškinys. Dažniausiai tèvai, matydami ir girdeddami plačiai skleidžiamą žiniasklaidos ir/ ar prevencinių programų informaciją apie seksualinę vaikų prievartą ir jos atpažinimo požymius, tampa jautrūs savo vaikų emociniams ir elgesio pokyčiams, todẻl jiems natūraliai kyla ịtarimai, jog taip galejjo atsitikti ir jiems. Skyrybų ginčuose, kuriuose dalyvaujančios šalys yra itin priešiškos viena kitos atžvilgiu, vienas iš tèvų, turèdamas pernelyg ribotus įrodymus, gali per greitai peršokti prie klaidingų išvadų. Tokiais atvejais bet kokios įtarimus keliančios aplinkybès gali skatinti tèvą užduoti vaikui įteikiančius klausimus ir pastiprinti bet kokị atžalos pritarimą (3).

Vertinant seksualinès vaiko prievartos įtarimus, kylančius skyrybų ginčuose, svarbu atsižvelgti ị laiką, kada ịta- 
rimai buvo pareikšti. Autoriai sutinka, jog dažniausiai klaidingi įtarimai kyla tada, kai skyrybos jau būna įvykusios, ir tėvai sprendžia su vaiko lankymu/bendravimo su juo klausimus. Specialistams labai svarbu kruopščiai įvertinti įvykių chronologiją, atkreipiant demesị ị tokius reikšmingus ịvykius, kaip teisinius manevrus bylos eigoje, naujų romantinių santykių atsiradimą vieno iš tèvų gyvenime ir pan. Jei nustatoma, jog skyrybos prasidejjo po to, kai kilo įtarimai dèl seksualinès vaiko prievartos, tada labiau tikètina, jog pareikšti ịtarimai teisingi (3).

Autoriai sutinka, jog klaidingi įtarimai dažniausiai kyla, kalbant apie mažesnio amžiaus vaikus. Tyrẻjų apskaičiavimu, daugelyje atvejų, kuriuose buvo pareikšti klaidingi įtarimai, vaikams buvo mažiau nei 5 metai. Specialistai pastebi, jog kuo mažesnis vaikas, tuo didesnè yra emocinè jo priklausomybė nuo tẻvų, todèl jis yra labiau pažeidžiamas ir lengviau pasiduoda piktų ir kerštingų gimdytojų manipuliacijoms. Taip pat, vertinant ịtarimų teisingumą, svarbu stebèti kaltinančio tèvo elgesị. Autoriai pažymi, jog, esant pagrịstiems ịtarimams, kaltinantis tèvas sielvartauja, yra susigèdęs, užsidaręs, nori, jog vaikas būtų apklausiamas vienas. Priešingai, klaidingų ịtarimų atvejais kaltinantysis dažnai demonstruoja poreikị visiems apie tai pasakoti, nenori girdèti kitų alternatyvių paaiškinimų, yra ịsitikinęs fakto teisingumu, išsako reikalavimus būti apklausoje kartu su atžala ir pan. $(2,3)$.

Dèl seksualinès vaiko prievartos pareikštų ịtarimų, kurie kyla skyrybų ginčuose, vertinimui yra svarbu analizuoti ne tik aukščiau aprašytus aspektus, tačiau būtina atsižvelgti ir ị vaiko parodymų charakteristiką bei asmenines ginčo šalių savybes. Autoriai pastebi, jog, esant teisingiems įtarimams, vaiko pasakojimas apie patiriamą seksualinę prievartą kyla spontaniškai, ir jis apima vaiko amžių atitinkantị konteksto, išskirtinių detalių ịvardijimą. Realistiškas vaiko pasakojimas taip pat yra dažniausiai susijęs su ji atitinkančiomis emocijomis bei apima tokias ịvykių aplinkybes kaip paslapties saugojimą ar grasinimus apie patiriamą prievartą niekam nepasakoti. Stipri vaiko neapykanta ịtariamajam dẻl neaiškių ir mažai reikšmingu priežasčiu labiau atspindi kaltinančio tèvo reakcijas bei retai kyla iš realios vaiko patirties. Taip pat pastebėtina, jog jei vaikas itin noriai pasakoja apie pareikštus ịtarimus, gali būti, jog toks jo pasakojimo būdas yra pastiprinamas kaltinančio tėvo. Kalbant apie individualias psichologines skyrybu ginčuose dalyvaujančių šalių savybes, autoriai sutinka, jog neretai kaltinantieji tėvai turi asmenybinių sutrikimų ir/ ar psichinių problemų, tačiau svarbu pabrèžti, jog pasitaiko atvejų, kad net ir isteriško tipo, karingai nusiteikusios moterys, kurios turi svarų motyvą kerštauti, pareikšdamos įtarimus dèl seksualinio vaiko išnaudojimo, gali pateik- ti svarių įrodymų, jog vaikas iš tiesų patiria prievartą (3).

Galiausiai įtarimų, pareikštų skyrybų ginčų metu, ịvertinimui ne mažiau svarbus ir pačių specialistų, dalyvaujančių tyrimo procese, elgesys. İtarimų vertinimo procese labai svarbu išlikti objektyviam ir atviram bei netureti išankstinių nuostatų nei apie ịtarimų teisingumą, nei apie jų klaidingumą. Autoriai aprašo, jog neretai klaidingų itarimų atvejai susiję su ankstyvu kontrolès praradimu, kai specialistai, dar neatlikę kruopštaus tyrimo, pateikia išvadas apie seksualinès prievartos faktą. Deja, pasitaiko ir tokių specialistų, kurie tampa kaltinančiujų tėvų sajungininkais, perimdami klaidingas jų prielaidas. Tokiais atvejais specialistai itin greitai priima sprendimą, jog vaikas buvo prievartaujamas, remdamiesi ribotais duomenimis, neịvertindami kitu alternatyvių galimybių bei ignoruodami ịrodymus, galinčius paneigti įtarimus. Dažnai minèta klaidinga išvada gali būti priimama, net nepasikalbejus su įtariamuoju, nors šis tokị prašymą išreiškia $(1,3)$.

Tiriamosios dalies darbo tikslas - nustatyti vaiko bendros šeimyninès situacijos ir elgesio ypatumus, galinčios turèti ịtakos, vertinant jo, kaip liudytojo apie seksualinị smurtą iš šeimos nario pusès, patikimumą.

\section{Tyrimo medžiaga ir metodai}

2009-2014 metais Vaikų ir paauglių TPS iš viso buvo atlikta 1099 ekspertizių. Iš jų 555, arba 51\%, - nukentejjusiems nuo seksualinès prievartos, iš kurių 76 atvejai, arba $7 \%$, kai ịtariamieji, atlikę seksualinio pobūdžio veiksmus vaikų atžvilgiu, buvo to vaiko tėvas arba motina. Tyrimui atrinkti 27 atvejai, kai itarimai dèl seksualinès prievartos buvo pareikšti tėvui arba motinai vykstančiu ar jau ịvykusių skyrybų kontekste. Nustatant vaiko bendros šeimyninès situacijos ir elgesio ypatumus, galinčios turèti ịtakos, vertinant jo kaip liudytojo apie seksualinį smurtą iš šeimos nario pusès patikimumą, buvo pasirinktas atvejo analizès tyrimo metodas. Validumo pagrindu pasitelkta skirtingu šaltinių trianguliacija, autentiškumo, kritiškumo ir integralumo kriterijai.

\section{Rezultatai ir ju aptarimas}

Iš mūsų analizuotų 27 atvejų 23 atvejais (81 proc.) mama ịtarẻ savo esamą/buvusị sutuoktini vaiko tvirkinimu. İtarimai asmenims pareikšti pagal 150 str. 4 p. (tas, kas tenkino lytinę aistrą su mažamečiu asmeniu prieš šio valią analiniu, oraliniu ar kitokio fizinio sąlyčio būdu panaudodamas fizinị smurtą ar grasindamas tuoj pat ji panaudoti, ar kitaip atimdamas galimybę priešintis, ar pasinaudodamas bejëgiška nukentejjusio asmens būkle), 153 str. (tas, kas atliko jaunesnio negu šešiolikos metų asmens tvirkinimo veiksmus). Vienam įtarimai nepareikšti, yra specialusis liu- 


\section{8}

dytojas. Konfliktiniai tėvų santykiai nustatyti 19 (70 proc.) atvejų. Didžiają dalį galimai nukentejusių vaikų sudarè mergaitès.

Tuo tarpu pagal amžiaus kriterijų išsiskyre ikimokyklinès vaikystès (nuo trejų iki 7 metų) tarpsnio grupè -12 atvejuc.

Teikiant teismui ekspertines išvadas, ar tiriamas vaikas galèjo duoti parodymus, 15 atvejų konstatuota, kad vaikas parodymus duoti gali, parodymai realistiški; 2 atvejais nustatyta, kad vaikas gali duoti parodymus, tačiau jis pats neigia ịtariamųjų galimai atliktus seksualinio pobūdžio veiksmus jų atžvilgiu. 12 atvejų apima ekspertines išvadas kaip „negalèjo duoti parodymų“, „gebèjimas duoti parodymus yra ribotas“, ,mažai tiketina, jog galejo duoti parodymus“. Šių išvadų prieita dèl mažo tiriamojo amžiaus (3 metukai), nuo byloje tiriamo laikotarpio praejo pernelyg ilgas laiko tarpas (tiriamajai $5 \mathrm{~m}$., o nuo įvykių praejo 2,5 metų; tiriamajai $7 \mathrm{~m}$., pirmojoje apklausoje dalyvavo mama, antroji apklausa atlikta po dvejų metų; tiriamajai 3 m., o byloje

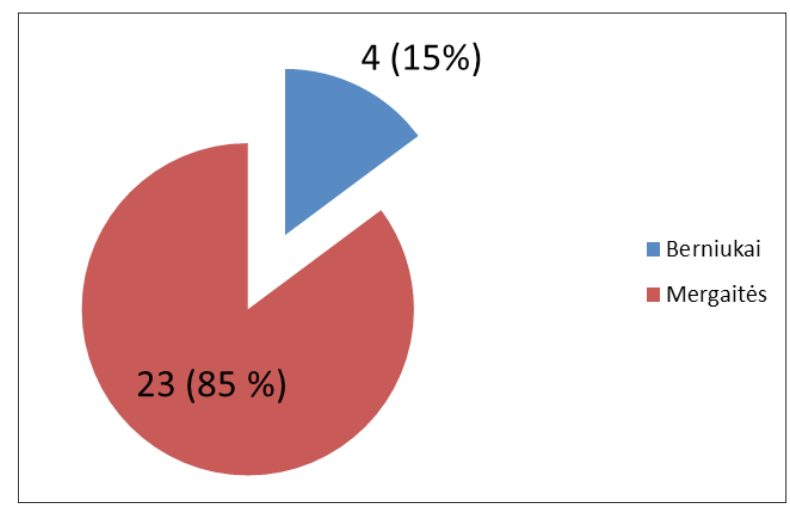

1 pav. Tiriamujų pasiskirstymas pagal lytị

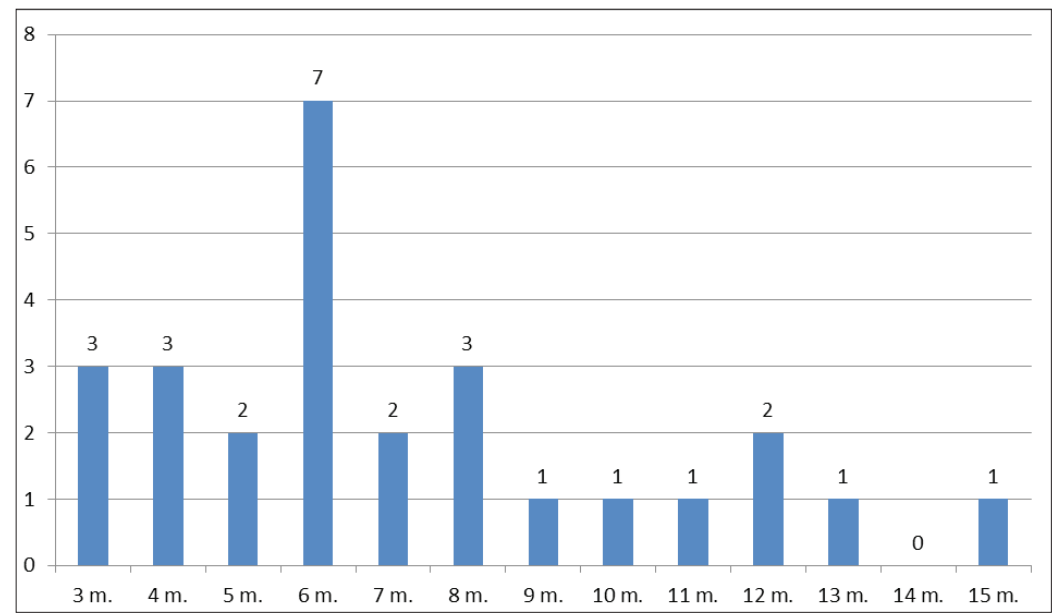

2 pav. Tiriamujų pasiskirstymas pagal lyti tiriami įvykiai jos 1 m. 5 mèn. -2 m. 10 mèn. amžiuje; tiriamajai $4 \mathrm{~m}$., o byloje tiriami ịvykiai jos vienerių-trejų metų amžiuje), dèl nustatyto tiriamiesiems daromo poveikio (du atvejai - kai poveikị dare ittariamasis; ir du - kai tai darè mama) bei dèl individualių psichologinių ypatumų (padidintas polinkis į ịtaigumą; negali visapusiškai teisingai suprasti aplinkos ịvykių dèl mažo amžiaus $(3 \mathrm{~m}$.) bei neigia galimai atliktus seksualinio pobūdžio veiksmus - du atvejai; padidintas polinkis fantazuoti, nutolę nuo realybès pasisakymai). Tuo tarpu psichiatro eksperto dažniausia išvada apie vaiko psichikos sveikatos sutrikdymo mastą psichiškai sveikas (3 pav.).

Atlikus visų ekspertizei pateiktų duomenu ir ekspertizès metu gautų duomenu lyginamąją analizę, išskirti specifiniai vaiko bendros šeimyninès situacijos ypatumai, kurie gali komplikuoti vaiko kaip liudytojo patikimumą, atkreipiant dèmesị i galimą suinteresuotų asmenų žalingą poveikị vaiko parodymų autentiškumui: a) tarp tėvų vyksta ilgalaikiai teisiniai ginčai dèl turto dalybų, gyvenamosios vietos nustatymo ir pasimatymų dažnio arba tẻvų santykiai akivaizdžiai konfliktiniai bei turi užsitęsusio konflikto eskalavimo požymių; b) dažniausiai nurodoma ịvykio vieta - atskirai gyvenančio ịtariamojo arba su jo pirmos eilès artimųu namai; c) iniciatyva dèl galimos nusikalstamos veikos išskirtinai nekreipiama teisine linkme, mažai kreipiant dèmesị ar ignoruojant medicininès ir ypač psichologinès pagalbos kelius, d) dažniausiai inicijuojant ịtarimą nuo liudijimo įvykio būna praèjęs neproporcingai didelis, atsižvelgiant ị vaikui galimai padarytą žalą, laiko tarpas; e) suinteresuotų asmenų, ypač tų, kurie nèra vaikui pirmos eilès giminaičiai (pavyzdžiui, seneliai), perdètai aktyvus, su agresyvumo elementais išvados apie padarytą žalą reikalavimas, šališki garsiai deklaruojamų simptomų ir kitais šaltiniais (psichologinio tyrimo iš darželio, mokyklos duomenys) nepatvirtinami vaiko elgesio ir asmenybès vertinimai; f) apsunkintas ar sutrikęs pačių suinteresuotų asmenų ryšys su vaiku: ignoruojami ar neatsižvelgiama ị vaiko poreikius ir savijautą, bendradarbiavimo deficitas, praeityje buvę fizinès nepriežiūros, faktinio globos perdavimo kitiems giminaičiams epizodai; g) vaiko ir ịtariamojo ryšio nebuvimas, kai nèra jokių prisiminimų apie bendrą patirtį iš epizodinès atminties, santykių vakuumas. Tiketina, kad tokiame vaiko mikrosistemos kontekste bus stebimi ir vaiko reagavimo specifiniai ypatumai, turintys diferencijuoto ir/arba hiperkompensatorinio elgesio požymių: a) vaikas apklausų, tyrimų metu 
pernelyg drąsiai, bet tuo pačiu paviršutiniškai įsitraukia i psichologinį kontaktą, demonstruodamas hiperaktyvumą ir dèmesio koncentracijos svyravimo požymius; b) pasakodamas apie patirtą smurtą, vaikas akivaizdžiai demonstruoja dvejopo elgesio požymius - teatrališkai kalba apie išgyvenimus, nepatvirtinamus jokiais neverbalinio bendravimo požymiais: c) liudijimo turinyje neproporcingai didelis neigiamų įtariamojo apibendrinimų kiekis, naudojant suaugusiųų žodyno sąvokas, frazes, vertinimo išsireiškimus; d) paauglio liudijimas, skirtingai nuo mažesnio amžiaus vai$\mathrm{ku}$, turi keršto dèl praeityje galimai patirto fizinio smurto motyvo elementų, panaudojant žinias, igytas per masinès informacijos priemones, plataus rezonanso sulaukusias laidas; e) vaikas savarankiškai nieko nepasako apie seksualinio smurto aplinkybes arba stereotipiškai ir inertiškai kartoja tas pačias banalias frazes; vaiko elgesys socialiai pageidaujamas; f) vaiko net bendru žinių spragos laisvai ir/ar lengvai užpildomos kita informacija; g) vaiko elgesys ne seksualizuotas, bet prieštaraujantis, nenuoseklus, siekiantis kitų dèmesio; h) vaikas pateikia nenuoseklias, prieštaringas, su hiperbolizavimo elementais, vaiko žinių ir kompetencijų lygio neatitinkančias, kaskart su naujais elementais įvykio aplinkybes, o atkreipus demesị, reaguoja gynybiškai.

Tuo tarpu analizuojant vaiko, kaip pakankamai patikimo liudytojo apie seksualini šeimos nario nusikaltimą, buvo išskirtos tokios bendros šeimyninès situacijos aplinkybės: a) nėra aiškių duomenų apie teisinius ginčus po skyrybų proceso ir/arba buvusių sutuoktinių tarpusavio santykiai pablogėja tik pareikštų itarimų kontekste; b) nurodoma ivvykio vieta - bendrai gyventa iki skyrybu arba po skyrybų vieta; c) iniciatyva dèl galimai vaiko patirto smurto iš pradžių nukreipiama ị medicinos ir/ar vaikų

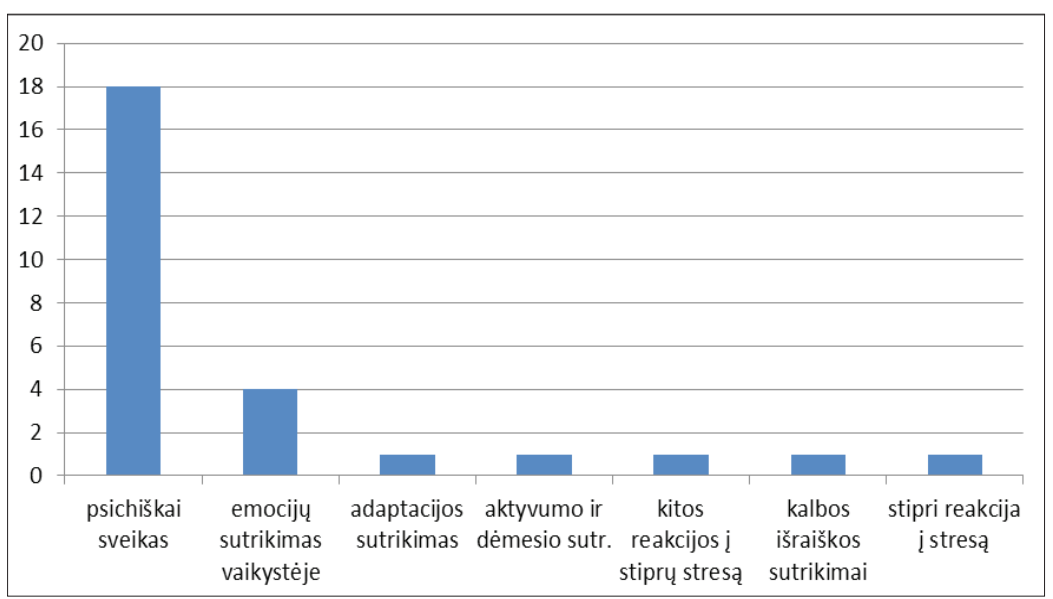

3 pav. Teismo psichiatrų nustatytos diagnozès pagal TLK-10-AM kriterijus psichologijos specialistus, vèliau psichologinè pagalba vaikui noriai derinama su teisiniu ịvykio pusès nagrinèjimu; d) vaikui atstovaujančios pusės pirmoji emocinè reakcija - išgąstis ar nerimas dèl vaiko, išreikštas poreikis pasitarti, kaip reaguoti i pasikeitusią situaciją; e) i vaiko pranešimą reaguojama neatidèliojant (gali būti kalbamasi su ịtariamuoju, kreipiamasi i vaiko sveikatos priežiūros ịstaigas); f) vaiko ir jo globejjo ryšys saugus, bendradarbiaujantis, bet ne vienintelis (kiti šeimos nariai); g) vaiko ir itariamojo ryšys neaugaus vengiančio arba neaugaus ambivalentiško bazinio prieraišumo tipo (vaiko prisiminimai iš epizodinès atminties emociškai nuspalvinti); h) emociškai artimų ryšių tarp tèvų praeityje stoka, galimi konfliktų su fizinio smurto elementais epizodai, kurie po skyrybų užsibaigè. Tuo pačiu išskirti ir vaiko, kaip pakankamai patikimo liudytojo apie seksualinį nusikaltimą iš šeimos nario, pasitaikantys elgesio ypatumai: a) laiko psichologinio kontakto užmezgimui būtinybè - vaikas įsidrąsina eigoje: b) apie seksualinị smurtą pasakoja su akivaizdžiais nerimo neverbaliniais požymiais - dažnai greitakalbe, jautriai reaguojant ị galimą kitų netikèjimą, ambivalencija; c) liudijimo turinyje dominuoja kelios kartotinai nurodomos konkrečios aplinkybès; d) vaiką globojantis asmuo kartoja vaiko žodžius, o ne priešingai.

Tokiu būdu įtarimai dèl seksualinio nusikaltimo prieš vaiką tėvų skyrybų atvejais nors ir nèra dominuojantys procentine dalimi bendroje seksualinių nusikaltimų statistikoje, tačiau reikalaujantys atidžiausių visų sričių specialistų - teisés, psichiatrijos, psichologijos - integruotų pastangų, išaiškinat visas svarbias aplinkybes teismui bei

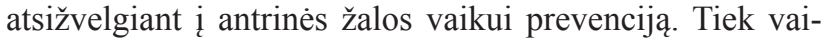
ko atžvilgiu įvykdytas seksualinis nusikaltimas iš šeimos nario pusès, tiek netikèjimas vaiko liudijimu, tiek suinteresuoto šeimos nario poveikis vaikui duoti indukuotus parodymus prieš kitą šeimos narị, net jei su juo nèra jokio emocinio ryšio, neabejotinai sukelia ilgalaikę žalą vaiko asmenybės raidai, kai pati patirta žala nèra kliniškai matoma ir sunkiai verifikuojama moksliniais bei medicininiais kriterijais.

\section{Išvados}

1. Klaidos, daromos vertinant ịtarimus dèl seksualinès vaiko prievartos, yra dvejopos, ir abi turi ilgalaikių neigiamu pasekmių visoms i procesą įtrauktoms šalims.

2. Klaidingai pareikštų įtarimų (kai seksualinès vaiko prievartos faktas nepasitvirtino) dažnumas yra nedidelis - mažiau nei 10 procentų nuo visų pareikštų įtarimų, ir šis rodiklis yra aukštesnis skyrybų ginčuo- 
se. Jei apie patiriamą lytinị smurtą pirmas pasipasakoja vaikas, klaidingų ịtarimų dažnumas dar labiau sumažeja.

3. Daugelis nespecifinių emocinių ir elgesio pokyčių, susijusių su seksualine vaiko prievarta, yra sąlygojami ir bet kokios kitos trauminès patirties. Amžiaus neatitinkantis seksualizuotas vaiko elgesys yra vienintelis požymis, labiausiai siejamas su seksualinès prievartos patirtimi, tačiau vertinantiems specialistams yra svarbu atskirti, koks su lytiškumu susijęs elgesys yra normalus vaiko amžiui, o dèl kurio reikètų susirūpinti. Minètų simptomų nebuvimas nepaneigia seksualinès prievartos fakto, kaip ir vien tik ju nustatymas nèra pakankama sąlyga, kad toks faktas būtų patvirtintas.

4. Pirminių vaiko parodymų, kurių metu buvo atskleistas seksualinès prievartos faktas, atsižadejjimas nèra retas reiškinys ir jis nebūtinai reiškia, jog pareikšti įtarimai yra teisingi arba klaidingi, tačiau tai yra svarbus signalas aplinkiniams, jog vaiko gyvenime ne viskas yra gerai, nepriklausomai nuo jo būsenos pokyčių priežasčių: seksualinės prievartos jo atžvilgiu, disfunkcijos šeimoje ar kitų stresogeninių situacijų ne artimiausioje vaiko aplinkoje.

5. Didžiausias klaidingų ịtarimų procentas (svyruoja nuo 20 iki 80 procentų) kyla skyrybų ginčuose dèl gyvenamosios vaiko vietos/bendravimo su juo tvarkos nustatymo, o jų vertinimą dar labiau komplikuoja mažas nukentejusiojo amžius, suaugusiujų motyvacija bei poreikis ginti teises ir interesus tiek paties vaiko, tiek ịtariamojo smurtautojo.

6. Dalis pareikštų ịtarimų dèl seksualinio vaiko išnaudojimo gali pasitvirtinti tik skyrybų ginčų metu, nes nukentejęs vaikas gali bijoti pasakoti apie smurtautojo veiksmus, kol visi šeimos nariai yra vis dar kartu; negyvenančiam tèvui yra daug sunkiau daryti aukai spaudimą nepasakoti apie prievartą, nukentejjęs vaikas gali jausti didelę baimę, prieš eidamas susitikti teismo paskirtu laiku su kartu negyvenančiu smurtautoju, todèl, siekdamas išvengti jų susidūrimo, gali imti pasakoti apie patirtą seksualinę prievartą.

7. Nespecifiniai emociniai ir elgesio pokyčiai, pasireiškiantys vaikams, kurių tevai skiriasi, bei simptomai, kurie yra susiję su seksualinės prievartos patyrimu, yra panašūs, todèl juos vertinantys specialistai turi būti susipažinę ne tik su jų etiologija, bet ir technikomis, kaip šiuos požymius teisingai susieti su konkrečia traumine patirtimi.

8. Nèra konkretaus testo, kurio pagalba skyrybu ginčuose kilę ịtarimai dèl seksualinès vaiko prievartos būtų patvirtinti arba atmesti, tačiau, siekiant juos visapusiškai ịvertinti, yra svarbu atsižvelgti ị daugeli aspektų: ịtarimų šaltini, jų atsiradimo laiką, vaiko amžių bei jo parodymų charakteristiką, skyrybų ginče dalyvaujančių šalių elgesị, jų asmenybines savybes bei vertinančių specialistų veiksmus.
9. Seksualinès vaiku prievartos atvejai yra sunkūs visiems. Profesionalai privalo būti objektyvūs ir atviri visiems duomenims, kurie yra prieinami. Specialistai privalo viską kruopščiai ịvertinti ir negali iš karto atmesti ịtarimų, jei jie yra pareikšti skyrybų ginčų kontekste. Tačiau tuo pat metu jie privalo vengti išankstinių nusistatymų, jog įtariamasis yra kaltas, ir turi gebèti netapti sajungininku bei aklai įtikèti kaltinančiojo pozicija.

10. Pareikštų įtarimų seksualiniu nusikaltimu prieš vaiką tèvų skyrybų atveju reikšmingais psichologinès analizès objektais turi būti vaiko tèvų konflikto dinamika sąlytyje su vaiko padètimi, vaiko prieraišumo pagrindai.

11. Vertinat vaiko, kaip liudytojo, patikimumą, būtina duomenų šaltinių trianguliacija ir liudijimo turinio autentiškumo verifikacija, atsižvelgiant ị diferencijuoto elgesio kriterijų.

\section{Literatūra}

1. Hey T. True and False Allegations of Child Sexual Abuse: Assessment and Case Management. New York: Brunner/Mazel Publishers. 1995.

2. Sparta SN, Koocher GP. Forensic Health Assessment of Children and Adolescents. Oxford University Press. 2006.

3. Wakefield H, Underwager R. Sexual Abuse Allegations in Divorce and Custody Disputes. Behavioral Sciences \& the Law 1991; 9(4): 451-468.

4. Čèsnienė I, Diržytė A. Nepilnamečių liudytojų parodymų baudžiamose bylose psichologinis vertinimas. Jurisprudencija, 2005; 67(59): 39-45.

\section{MINOR VICTIMS OF SEXUAL ABUSE - IMPORTANCE OF PSYCHOLOGICAL (EXPERT) ASSESSMENT IN DETERMINING FALSE ALLEGATIONS} D. Prižginè, A. Šiaulytė

Key words: children sexual abuse, assessment of allegations of children sexual abuse, children sexual abuse and conflictual divorce cases.

Summary

Cases of children sexual abuse are difficult to investigate, because often minor victims are not only the essential, but also the sole witnesses of the process. The assessment becomes even more complex, when the allegations of child sexual abuse originate in the context of conflictual parental divorces. Purposes of this article are to 1) overview the literature of the topic, 2) to overview of factors, influencing the minor victim as a reliable witness in such cases, 3) using case study method to analyze the data of forensic psychiatric-psychological assessments obtained in 2009-2014 at the department of forensic psychiatry of children and adolescents, when the allegations of child sexual abuse were brought to minor's father or mother in the context of parental divorce.

Correspondence to: agne.siaulyte@vtpt.lt

Gauta 2015-10-05 